Dhaka Univ. J. Biol. Sci. 29(2): 147-153, 2020 (July)

\title{
ANTAGONISTIC POTENTIALS OF SELECTED SOIL FUNGI AGAINST THREE PATHOGENIC FUNGI OF TAGETES ERECTA L. AND T. PATULA L. ${ }^{1}$
}

\author{
MahfuZa AKTAR AND SHAmim SHAMsi* \\ Department of Botany, University of Dhaka, Dhaka-1000, Bangladesh
}

Key words: Antagonistic potentiality, Soil fungi, Pathogenic fungi, Blight, Tagetes spp.

\begin{abstract}
Three antagonistic fungi were isolated from the field soil of blight infected Tagetes spp. by serial dilution method. The fungi were identified as Aspergillus flavus Link, A. niger van Tiegh. and Trichoderma viride Pers. Antagonistic potentiality of aforesaid fungi were evaluated against the pathogenic fungi of Tageteserecta L. and T. patula L. following "dual culture colony interaction" and volatile and nonvolatile metabolites. The pathogenic fungi were A. alternata, Aspergillus fumigatus and Curvularia lunata. In dual culture colony interaction, out of three soil fungi, T. viride showed the highest growth inhibition on A. alternata $(71.03 \%)$, A. fumigatus $(38.49 \%)$ and C. lunata $(60.71 \%)$. The maximum inhibition of radial growth of $A$. alternata $(74.55 \%)$ was observed with the culture filtrates of T. viride owing to volatile metabolites. The maximum inhibition of radial growth of $A$. fumigatus $(37.43 \%)$ was observed with the culture filtrates of A. flavus owing to volatile metabolites. The complete inhibition of radial growth of $C$. lunata was observed with the culture filtrates of $A$. niger owing to volatile metabolites. The complete inhibition of radial growth of $A$. alternata was observed with nonvolatile metabolites of $A$. nigera and T. viride at all concentrations. The complete inhibition of radial growth of $A$. fumigatus was also observed with nonvolatile metabolites of $A$. niger at all concentrations. Aspergillus niger and T. viride may be exploited commercially as a biocontrol agent against blight pathogens of $T$. erecta and $T$. patula.
\end{abstract}

\section{Introduction}

The genus Tagetes is composed mostly of herbaceous plants in the sunflower family Asteraceae (Compositae). It was described as a genus by Linnaeus in 1753. It has 56 species in the sunflower family. The marigold is widely cultivated in India and Thailand. Tagetes erecta and T. patula are native to North and South America, but now has become naturalized around the world. In Bangladesh these two species are commonly grown by the gardeners as annual plants (Ahmed et al. 2008). Leaves are used as blood clotting agents in Ayurbedhic treatment. Plant is also used against fever, dysenteries, indigestions, ulcers and eczemas (Ghani 2003 and Yusuf et al. 2009). The plant has insecticidal effect (Fajana et al. 2009). Seeds of T. erecta is a natural pesticide. It is most

*Author for correspondence: <prof.shamsi@gmail.com>. ${ }^{1} \mathrm{~A}$ part of the work of the first author (MA) for her higher studies leading to Ph.D. 
effective against the nematode species Pratylenchus penetrans (Abid and Maqbul 1990, Olabiyi and Oyedunmade 2000 and Politi et al. 2012). Rajasekaran et al. (2004) reported mosqutocidal potentiality of the plant. Farmers in Jessore and Jhenaidah district cultivate marigold as commercial basis. The yield of marigold was 2,650,447 flowers per hectare. The gross margin and net return were Tk.1,62,186 and 1,17,812 per hectare, respectively. The net return was $80 \%$ higher than lentil, $85 \%$ higher than mustard and $6 \%$ lower than potato cultivation. Diseases were major constrain for marigold cultivation (Hoque et al. 2012). Leaf spot and blight are two common diseases of Tagetes spp. Mukerji and Bhasin (1986) reported disease of Tagetes from India. From Bangladesh powdery mildew, gray mold and white mold of marigold has been reported (Bakr et al. 2010, Sultana and Shamsi 2011 and Rahman et al. 2015). Aktar and Shamsi (2018) reported blight disease of T. erecta and T. patula from Bangladesh.

Fungicides are biochemical compounds or biological organisms used to kill parasitic fungi or their spores. The increasing use of chemical pesticides negatively affects the environment and human health. Use of chemical pesticides provides excellent control of the diseases and result in improved yield. But most fungicides can cause acute toxicity, and some cause chronic toxicity as well (Goldman 2008).

Biological control of plant diseases including fungal pathogens has been considered a viable alternative method to chemical control. Biological control presents a better alternative with relative low cost, without any side effects (Fokkema 1976)).

Study of antagonist as biocontrol agent has now become one of the most exciting and rapidly developing areas in plant pathology because it has great potential to solve many agricultural and environmental problems. At present, Trichoderma-based products are considered as relatively novel biological control agents which can help farmers to reduce plant diseases and increase plant growth (Trans 2010 and Tiwari et al. 2011).

However, in Bangladesh limited studies have been done in this regard (Helal and Shamsi 2019 and Yasmin and Shamsi 2019). Hence, the present investigation was undertaken to find out the in vitro antagonistic effect of Aspergillus flavus, A. niger and Trichoderma viride on the growth of A. alternata, A. fumigatus and C. lunata.

\section{Materials and Methods}

Twenty species of fungi were isolated from infected parts of T. erecta and T. patula during the period of 2009 to 2014 . Among the isolated fungi three were found pathogenic to both the species of Tagetes (Aktar and Shamsi 2018). The pathogenic fungi were Alternaria alternata, A. fumigatus and C. lunata. These three fungi were selected as test pathogen against three antagonistic fungi.

Serial dilution method was used to isolate antagonistic fungi from rhizophere soil of the host varieties. Among the isolated soil fungi, Aspergillus flavus, A. niger and 
Trichoderma viride were selected to test their antagonistic potential against the pathogens following dual culture technique.

Aforesaid antagonistic fungi were recently tested on fungal isolates obtained from Carica papaya L. and Rauwolfia serpentina (L.) Benth. ex Kurz. which were found effective against the test fungi (Helal and Shamsi 2019, Yasmin and Shamsi 2019). The parameter used for the assessment of the colony interaction and per cent inhibition of radial growth was calculated. Effects of volatile and non-volatile metabolites of the selected soil fungi against the test pathogens were also studied following Bashar and Rai (1994). Data on different parameters were analyzed following computer package MSTAT-C and means were compared using DMRT. The data were collected and evaluated by ANOVA by using STAR statistical program followed by Yasmin and Shamsi (2019).

\section{Results and Discussion}

The results of colony interactions are summarized in Table 1. In dual culture colony interaction A. flavus, A. niger and T. viride showed 53.06, 54.49 and $71.03 \%$ growth inhibiting effect on A. alternata (Table 1). The same antagonistic fungi showed 29.9, 32.26 and $38.49 \%$ growth inhibition on A. fumigatus (Table 1). The same antagonistic fungi also showed $41.06,43.94$ and $60.71 \%$ growth inhibition on C. lunata (Table 1 ).

Table 1. Effect of antagonists on the radial growth of Alterenaria alternata, A. fumigatus and $C$. lunata.

\begin{tabular}{|c|c|c|c|c|c|c|c|}
\hline \multirow{3}{*}{$\begin{array}{l}\text { Name of } \\
\text { antagonists }\end{array}$} & \multirow{3}{*}{ Type } & \multicolumn{6}{|c|}{$\%$ inhibition of radial growth and intermingled zone of the test pathogens } \\
\hline & & \multicolumn{2}{|c|}{ A. alternata } & \multicolumn{2}{|c|}{ A. fumigatus } & \multicolumn{2}{|c|}{ C. lunata } \\
\hline & & $\begin{array}{l}\% \text { inhibition } \\
\text { of growth }\end{array}$ & $\begin{array}{l}\text { inter- } \\
\text { mingled } \\
\text { zone }(\mathrm{cm})\end{array}$ & $\begin{array}{l}\text { \% inhibi- } \\
\text { tion of } \\
\text { growth }\end{array}$ & $\begin{array}{l}\text { inter- } \\
\text { mingled } \\
\text { zone }(\mathrm{cm})\end{array}$ & $\begin{array}{l}\text { \% inhibi- } \\
\text { tion of } \\
\text { growth }\end{array}$ & $\begin{array}{l}\text { inter- } \\
\text { mingled } \\
\text { zone }(\mathrm{cm})\end{array}$ \\
\hline $\begin{array}{l}\text { Aspergillus } \\
\text { flavus }\end{array}$ & Bii & 53.06 & 0.2 & 29.9 & 0.17 & 41.06 & 0.1 \\
\hline A.niger & Bii & 54.49 & 0.2 & 32.26 & 0.2 & 43.94 & 0.17 \\
\hline $\begin{array}{l}\text { Trichoderma } \\
\text { viride }\end{array}$ & Bii & 71.03 & 0.17 & 38.49 & 0.25 & 60.71 & 0.2 \\
\hline
\end{tabular}

Bii = Intermingling growth where the fungus under observation has ceased the growth and is being overgrown by another colony (2).

In contrast to the present study, Aktar et al. (2014) reported that in dual culture colony interaction Aspergillus niger, Trichoderma viride, A. flavus and A. fumigatus showed $75.87,75.5,51.78$ and $45.52 \%$ growth inhibition on C. lunata. This variation might be due to selection of different test pathogens. In dual culture technique, significantly maximum inhibition was recorded in T. viride (66.40\%) according to Patel and Joshi (2001). 
The results of the effect of volatile metabolites on antagonistic fungi against marigold pathogens are presented in Table 2. The maximum inhibition of radial growth of $A$. alternata was observed with volatile metabolites of $T$. viride which was $74.55 \%$ followed by $A$. flavus $61.82 \%$ and. A. niger $28.49 \%$. The maximum inhibition of radial growth of $A$. fumigatus was observed with volatile metabolites of $A$. flavus that was $37.43 \%$ followed by T. viride $28.07 \%$ and $A$. niger $16.38 \%$. The complete inhibition of radial growth of C. lunata was observed with volatile metabolites of $A$. niger and that was $100 \%$ followed by $T$. viride $83 \%$ and $A$. flavus $81.37 \%$ after 6 days of incubation at $25 \pm 2^{\circ} \mathrm{C}$.

Table 2. Per cent inhibition of radial growth of the test pathogens by volatile metabolites of antagonistic fungi.

\begin{tabular}{lccc}
\hline \multirow{2}{*}{$\begin{array}{l}\text { Name of } \\
\text { antagonist }\end{array}$} & \multicolumn{3}{c}{ \% inhibition of radial growth of the test pathogens } \\
\cline { 2 - 4 } & A. alternata & A. fumigatus & C. lunata \\
\hline Aspergillus flavus & $61.82^{\mathrm{b}}$ & $37.43^{\mathrm{a}}$ & $81.37^{\mathrm{b}}$ \\
A. niger & $28.49^{\mathrm{c}}$ & $16.38^{\mathrm{c}}$ & $100^{\mathrm{a}}$ \\
Trichoderma viride & $74.55^{\mathrm{a}}$ & $28.07^{\mathrm{b}}$ & $83.00^{\mathrm{b}}$ \\
\hline
\end{tabular}

Mean followed by the same superscript letter(s) within a column did not differ significantly at $5 \%$ level by LSD.

In contrast to the present study, Aktar et al. (2014) reported that volatile metabolites produced by an isolate of $A$. niger, A. flavus, A. fumigatus and T. viride inhibited the mycelial growth of Colletotrichum sp. by 14.68, 11.78, 11 and 11\%, respectively Further the volatile metabolites produced by isolates of T. viride, A. niger, A. flavus and A. fumigatus inhibited the mycelia growth of Fusarium semitectum by 13.5, 9.5, 8 and 7.75\%, respectively. Differences in per cent inhibition with the present study might be due to the difference in organism involved in the interaction. Thakur and Harsh (2014) reported that volatile metabolites produced from the culture of $A$. niger showed $42.43 \%$ inhibition of mycelia growth of $C$. gloeosporioides.

Table 3 shows the effect of nonvolatile metabolites on the growth of A. alternata, A. fumigatus and C. lunata. Nonvolatile metabolites of $A$. niger and T. viride showed complete radial growth inhibition of $A$. alternata at all concentrations. Aspergillus flavus at $20 \%$ concentration showed maximum $56.1 \%$ inhibition of $A$. alternata followed by A. fumigatus $52.12 \%$ and C. lunata $30.77 \%$. The complete inhibition of the radial growth of Aspergillus fumigatus was observed with nonvolatile metabolites of $A$. niger at all concentrations used. Volatile metabolites of $A$. niger showed maximum $47.44 \%$ radial growth inhibition of C. lunata at $20 \%$ concentration followed by T. viride $35.90 \%$.

In contrast to the present study, Aktar et al. (2014) reported that nonvolatile metabolites produced by an isolate of A. niger, Trichoderma viride, A. flavus and A. fumigatus inhibited the mycelia growth of Colletotrichum sp. by 52.56, 44.72, 40.0 and 
$37.2 \%$, respectively. Further, the nonvolatile metabolites produced by an isolate of $T$. viride, A. niger, A. flavus and A. fumigatus inhibited the mycelia growth of F. semitectum by $50,45,8$ and $7.75 \%$, respectively. Differences in per cent inhibition with the present study might be due to the difference in organism strain involved in the interaction. Madhanraj et al. (2010) reported that culture filtrates of T. viride and A. niger inhibited the mycelial growth of $F$. solani by 85 and $70 \%$ at $20 \%$ concentration, respectively. Tran (2010) used T. viride to control S. rolfsii and found effective result.

Table 3. Per cent inhibition of radial growth of test pathogens by nonvolatile metabolites of antagonistic fungi.

\begin{tabular}{lcccc}
\hline \multirow{2}{*}{$\begin{array}{l}\text { Name of } \\
\text { antagonist }\end{array}$} & $\begin{array}{c}\text { Concentrations } \\
(\%)\end{array}$ & \multicolumn{3}{c}{$\%$ inhibition of radial growth of test pathogens } \\
\cline { 3 - 5 } & 5 & $21.95^{\mathrm{b}}$ & $33.34^{\mathrm{b}}$ & $10.26^{\mathrm{ab}}$ \\
\hline Aspergillus flavus & 5 & $46.34^{\mathrm{b}}$ & $45.46^{\mathrm{b}}$ & $30.77^{\mathrm{a}}$ \\
& 10 & $56.10^{\mathrm{b}}$ & $52.12^{\mathrm{b}}$ & $37.82^{\mathrm{b}}$ \\
Aspergillus niger & 20 & $100^{\mathrm{a}}$ & $100^{\mathrm{a}}$ & $7.69^{\mathrm{a}}$ \\
& 5 & $100^{\mathrm{a}}$ & $100^{\mathrm{a}}$ & $18.59^{\mathrm{b}}$ \\
& 10 & $100^{\mathrm{a}}$ & $100^{\mathrm{a}}$ & $47.44^{\mathrm{a}}$ \\
Trichoderma viride & 20 & $100^{\mathrm{a}}$ & $13.04^{\mathrm{c}}$ & $13.46^{\mathrm{a}}$ \\
& 5 & $100^{\mathrm{a}}$ & $25.36^{\mathrm{c}}$ & $20.51^{\mathrm{b}}$ \\
& 10 & $100^{\mathrm{a}}$ & $36.96^{\mathrm{c}}$ & $35.90^{\mathrm{b}}$ \\
\hline
\end{tabular}

Mean followed by the same letter(s) within a column did not differ significantly at $5 \%$ level by LSD.

Tiwari et al. (2011) tested two biocontrol agents viz., Aspergillus niger and Trichoderma viride were tested against ten white rot and one brown rot wood decay fungi (WDF) by dual culture technique under laboratory conditions. The result showed that both A. niger and T.viride inhibit growth of all WDF tested. The percentage inhibition of radial growth values of $T$. viride and A. niger are almost the same (ranging from 29.2 to $66.7 \%$ ) and the average mean value of T. viride (51.7\%) is $13.3 \%$ more than that $A$. niger $(45.5 \%)$.

In Bangladesh Tagetes erecta and T. patula are commonly grown by the gardeners as annual plants. The essential oil from this plant is being investigated for antifungal activity, including treatment of candidiasis and treating fungal infections in plants. The plant is used in companion planting for many vegetable crops. Both the species are used in Ayurvedic treatment. Plant has also mosqutocidal potentiality. Ninety five per cent farmers in Jessore and Jhenaidah districts cultivate marigold as commercial basis. Due to rapid expansion of commercial marigold cultivation many diseases appear on the plants. 
Though marigold is presently a profitable cultivated crop to the farmers in Bangladesh but socioeconomic data and information of this flower are very scarce.

Present research suggested that $A$. niger and $T$. viride may be exploited commercially as a biocontrol agent against blight pathogens of T. erecta and T. patula. Moreover the present investigation will be helpful for designing an ecofriendly management of blight disease of Tagetes spp.

\section{Acknowledgements}

The authors express their gratitude and thanks to "Research and Higher Education Fund of the Prime Minister's Office, Govt. of People's Republic of Bangladesh" for the financial support in the form of scholarship during the tenure of research work.

\section{References}

1. Ahmed ZU, ZNT Begum, MA Hassan and M Khondker, SMH Kabir, M Ahmed, ATA Ahmed, AKA Rahman, AKA Haque EU (eds.) 2008. Encyclopedia of Flora and Fauna of Bangladesh, Vol. 6 Angiosperms: Dicolyledons (Acanlhaceae-Asteraceae). Asiatic Society of Bangladesh, Dhaka, 408 pp.

2. Ghani A 2003. Medicinal plants of Bangladesh. Asiatic Society of Bangladesh. pp. 603.

3. Yusuf M, J Begum, MN Hoque and JU Chowdhury 2009. Medicinal plants of Bangladesh. BCSIR Laboratories, Chittagong. pp. i-x+794.

4. Farjana N, MR Habib, MR Karim, Z Ferdousi, MM Rahman and ME Haque 2009. Insecticidal activity of flower of Tagetes erecta L. against Tribolium castaneum. (Herbst). Res. J. Agri. Bio. Sci. 5(5): 748-753.

5. Abid M and MA Maqbool 1990. Effect of intercropping of Tagete serecta on root-knot disease and growth of tomato. Int. Nematol. Network Newsl. 7: 41-42.

6. Olabiyi T and EEA Oyedunmade 2000. Marigold (Tagetes erecta L.) as interplant with cowpea for the control of nematode pests. Proceedings of African Crop Science Conference 8: 1075-1078.

7. Politi F A, CM Figueria, AM Arúio, BR Sampieri, MI Mathias, MP Szabó, GH Bachara, LCD Santos, W Vilegas and RC Pietro 2012. Acaricidal activity of ethanoloi extract from aerial parts of Tagetes patula L. (Asteraceae against larvae and engorged adult females of Rhipicephalus sanguineus (Latreille, 1806). Parasit Vectors 17(5): 295.

8. Rajasekaran T, GA Ravishankar and B Reddy 2004. In vitro growth of Tagetes patula L. hairy roots production of thiophenes and its mosquito larvicidal activity. Indian Journal of Biotechnology 3: 92-96.

9. Hoque MA, M Monayem, S Hossain and M Alam 2012. Economics of marigold cultivation in some selected area of Bangladesh. Bangladesh J. Agril. Res. 37(4): 711-720.

10. Mukerji KG andJ Bhasin1986. Plant diseases of India. A source Book. Tatta Mc.Grew-Hill Publishing Company Ltd. New Delhi. 468 pp.

11. Bakr MA, MS Hossain and HU Ahmed 2010. A guide to disease identification, data recording,rating scale and grading system of major diseases of important crops. Oilseed Research Centre. Joydebpur, Gazipur, Bangladesh. pp. 74 
12. Sultana R. and S Shamsi 2011. Alternative and collateral hosts of Botrytis cinerea causing Botrytis Grey mold of chickpea in Bangladesh. Bangladesh J. Plant Pathol. 27(1\&2): 73-74.

13. Rahman D, M Hossain, TK Dey, SR Sarker, M Nonaka and N Harada 2015. First report of white mould caused by Sclerotinia sclerotiorum on Marigold (Tagetes erecta) in Bangladesh. J. Plant Pathol. 97(2): 391-403.

14. Aktar M and S Shamsi 2018. Incidence and severity of blight disease of Tagetes erecta and T. patula. Bioresearch Communications 4(1): 464-469.

15. Goldman LR 2008. Encyclopedia of Public Health: Fungicides. Cited on 6 June 2008, available fromhttp:/www.answers.com/topic/fungicide?cat=technology.

16. Fokkema NJ 1976. Antagonism between fungal saprophytes and pathogens on aerial plant surfaces. In: Microbiology of Aerial Plant Surfaces (eds. Dickinson CH and Preece TF), Academic Press, London. pp. 487-505.

17. Tran N Ha 2010. Using Trichoderma species for biological control of plant pathogens in Viet Nam. J. ISSAAS 16(1): 17-21.

18. Tiwari CK, J Parihar and RK Verma 2011. Potential of Aspergillus niger and Trichoderma virideas biocontrol agents of wood decay fungi. Journal of the Indian Academy of Wood Science. 8(2): 169-172.

19. Helal RB and S Shamsi 2019. Antagonistic potential of soil fungi against three post-harvest pathogenic fungi of Carica papaya L. Dhaka Univ. J. Biol. Sci. 28(1): 1-7.

20. Yasmin Z and S Shamsi 2019. Antagonistic potential of soil fungi against Colletotrichum gloeosporioides (Penz.) Sacc., the causal agent of Rauwolfia serpentina (L.) Benth. ex Kurz. Dhaka Univ. J. Biol. Sci. 28(2): 219-226.

21. Bashar MA and B Rai 1994. Antagonistic potential of root-region microflora of chickpea against Fusarium oxysporum f. sp. ciceri. Bangladesh J. Bot. 23(1): 13-19.

22. Skidmore AM and CH Dickinson 1976. Colony interaction and hyphal interference between Septoria nodorum and phylloplane fungi. Trans. Brit. Mycol. Soc. 66: 57-64.

23. Aktar MT, KS Hossain and MA Bashar 2014. Antagonistic potential of rhizosphere fungi against leaf spot and fruit rot pathogens of brinjal. Bangladesh J. Bot. 43(2): 213-217.

24. Patel KD and Joshi KR 2001. Antagonistic effect of some bioagents in vitro against Colletotrichum gloeosporioides Penz. and Sacc. The causal agent of leaf spot of turmeric. J. Mycol. and PI. Path. 31: 126.

25. Thakur S and NSK Harsh 2014. In vitro potential of volatile metabolites of phylloplane fungi of Piper longumas biocontrol agent against plant pathogen. International Journal of Science and Nature 5(1): 33-36.

26. Madhanraj P, V Ambikapathy and A Panneerselvam 2010. Biological control of banana wilt caused by Fusarium solani (Mart.) Sacc. International Journal of Applied Biology and Pharmaceutical Technology 1(3): 1032-1039. 